\title{
Age and Gender Differences in Experience with and Connectedness to Nature Among Children
}

\author{
Nor Diyana Mustapa ${ }^{1}$, Khalilah Hassan ${ }^{1}$, Siti Nuratirah Che Mohd Nasir ${ }^{1}$, Wenny Arminda ${ }^{2}$ \\ ${ }^{1}$ Faculty of Architecture and Ekistics, Universiti Malaysia Kelantan, Malaysia \\ ${ }^{2}$ Department of Architecture, Institut Teknologi Sumatera, Indonesia
}

diyana.m@umk.edu.my, khalilah.h@umk.edu.my, nuratirah.mn@umk.edu.my, wenny.arminda@ar.itera.ac.id Tel: +6011-10859544

\begin{abstract}
This study aims to identify the age and gender differences in children's experiences with nature and their connectedness to nature (CTN). This study employed a quantitative approach and involved 760 children aged 10-11 years old, including urban and rural children in Kedah and Pulau Pinang. Questionnaires were distributed to children at schools. Findings suggest that age and gender do influence the frequency of children having experiences with nature as well as their CTN. The directions for future research are also discussed.
\end{abstract}

Keywords: experiences with nature; connectedness to nature; age; gender

eISSN: 2398-42870 2021. The Authors. Published for AMER ABRA cE-Bs by e-International Publishing House, Ltd., UK. This is an open access article under the CC BYNC-ND license (http://creativecommons.org/licenses/by-nc-nd/4.0/). Peer-review under responsibility of AMER (Association of Malaysian Environment-Behaviour Researchers), ABRA (Association of Behavioural Researchers on Asians/Africans/Arabians) and cE-Bs (Centre for Environment-Behaviour Studies), Faculty of Architecture, Planning \& Surveying, Universiti Teknologi MARA, Malaysia.

DOI: https://doi.org/10.21834/ebpj.v6i16.2707

\subsection{Introduction}

Many studies have demonstrated that an individual attachment to nature, known as connectedness to nature (CTN), plays a vital role in developing a positive attitude and behaviour towards the environment. Indeed, CTN has positively influenced people's environmental concerns and behaviours (Zhang, Goodale, \& Chen, 2014). Researchers have also found that CTN has a positive impact on an individual's psychological well-being, as it positively correlates with mindfulness (Howell, Dopko, Passmore, \& Buro, 2011) and happiness (Capaldi, Dopko, \& Zelenski, 2014). Given the many benefits of CTN regarding individual attitudes towards nature and the environment, as well as psychological well-being, the question now is how an individual develops their CTN. Many studies have demonstrated that frequent experiences with and in nature are the most significant factor that contributing to an individual's CTN, which subsequently influences their environmental concerns and behaviours (Mustapa, Maliki, \& Hamzah, 2018; Zhang et al., 2014).

However, rapid urbanization and population growth, which mostly occur in developing countries, have reduced children's experiences with nature especially direct experiences. Children's spontaneous and unstructured experiences with nature in the backyard, field, and natural areas in their neighbourhood have decreased (Gundersen, Skår, O'Brien, Wold, \& Follo, 2016; Mustapa, Maliki, Aziz, \& Hamzah, 2018). Modernization and parental restrictions have also caused children's leisure activities to change from them being actively involved in outdoor activities where nature exists to being passively confined to indoor activities, aided by gadgets (Holt, Lee, Millar, \& Spence, 2015). For that reason, children have obtained experiences with nature mostly from indirect experiences through the media and books, as well as in classes and visits to organized natural places, such as zoos (Louv, 2008; Mustapa, Maliki,

eISSN: 2398-42870 2021. The Authors. Published for AMER ABRA cE-Bs by e-International Publishing House, Ltd., UK. This is an open access article under the CC BYNC-ND license (http://creativecommons.org/licenses/by-nc-nd/4.0/). Peer-review under responsibility of AMER (Association of Malaysian Environment-Behaviour Researchers), ABRA (Association of Behavioural Researchers on Asians/Africans/Arabians) and cE-Bs (Centre for Environment-Behaviour Studies), Faculty of Architecture, Planning \& Surveying, Universiti Teknologi MARA, Malaysia.

DOI: https://doi.org/10.21834/ebpj.v6i16.2707 
Aziz, et al., 2018). The phenomenon of disconnection has negative impacts on the well-being of both children and the environment. Gaps between children and nature may breed apathy towards the natural environment (Zhang et al., 2014). As the renowned ecologist Aldo Leopard (1949) once wrote, "We abuse land because we regard it as a commodity belonging to us. When we see land as a community to which we belong, we may begin to use it with love and respect" (as cited in Tam, Lee, \& Chao, 2013, p.1). Hence, it is crucial to reconnect the children with nature at an early age to instil love and respect for the land because they are its future guardians.

Even though many studies have debated the importance of childhood experiences with nature and CTN, little is known on age and gender differences in nature experiences, including direct, indirect, and non-nature experiences and CTN among children. Moreover, few studies have examined children's experiences with nature and CTN among Malaysian children. Most studies on children's experiences with nature and CTN have been conducted in Western countries, and few have been conducted in Asian countries. It is important to fill this gap because studies have found that people with different cultures have a different engagement with nature (Milfont, 2012), as well as different environmental attitudes and behaviours (Deng, 2006). Therefore, this study aims to identify the age and gender differences in children's experiences with nature and their CTN.

\subsection{Literature Review}

\subsection{Children and Nature}

Many studies have demonstrated that children appreciate and are most attracted to the natural environment (Korpela, Kyttä, \& Hartig, 2002; Mahidin \& Maulan, 2012), specifically, places with trees and flowers (Castonguay \& Jutras, 2009). The natural environment has become one of the children's favourite places because, for them, nature has a sense of magic, wonder, and imagination (Torquati \& Ernst, 2013). Natural elements, such as trees, grass, flowers, sand, and soil, allows children to be creative and imaginative. The diversity of natural elements offers challenging and exciting activities that promote creative play (Fjørtoft \& Sageie, 2000), where children can build their small world using natural elements. Previous studies have shown that the most preferred natural element is trees because children can use trees to play games such as hiding or climbing (Ridgers, Knowles, \& Sayers, 2012; Torquati \& Ernst, 2013) or they can pick fruit and touch moss. Children also prefer to play with water (Torquati \& Ernst, 2013), grass, flowers, soil, and sand (Salı, Akyol, \& Baran, 2014), as well as with animals (Sorin \& Gordon, 2012). The bonding between children and nature can be explained by ecopsychology perspectives that claim that children have an innate feeling to be connected with nature since birth (Phenice \& Griffore, 2003). This is similar to E. O. Wilson (1984) suggestion in the biophilia hypothesis that this innate feeling to be connected to nature is a gene.

\subsection{Age and Gender Differences in Children and Nature Relationship}

As for gender, many studies have demonstrated that girls across cultures have a stronger bond with nature than have boys (Zelezny, Chua, \& Aldrich, 2000). This may be because girls are more active in the garden, whereas boys are more independently mobile (Prezza et al., 2001), as they tend to be involved in sporting activities and can explore the vacant areas away from home (Min \& Lee, 2006). In another study, Alp, Ertepinar, Tekkaya, and Yilmaz (2006) also found that girls are more connected to nature and exhibit more positive attitudes towards the environment. Similarly, studies with adults also suggest that females have higher CTN (Mayer \& Frantz, 2004; Zelezny et al., 2000). However, a study with young children revealed no gender differences in their attitude towards the environment (Kahriman-Ozturk, Olgan, \& Tuncer, 2012). Collado and Corraliza's (2012) study also indicated no significant gender differences regarding environmental orientation.

Regarding age, studies have shown that older children (10-12 years old) are more independent in their mobility when they play outdoors as compared to younger children (7-9 years old) (Castonguay \& Jutras, 2009; Prezza et al., 2001). Thus, older children may have more experiences in nature compared to younger children. In contrast, Collado and Corraliza (2012) found that younger children (6-8 years old) are more explorative and are more fascinated by nature than are older children (10-13 years old). However, it is beyond the scope of this study to evaluate the differences between younger and older children since this study was conducted only with children aged 10 and 11 years old. Thus, this study examines only the differences in the experiences in nature and CTN between children aged 10 and 11 years old.

\subsection{Methodology}

\subsection{Participants and Methods}

This study employed a quantitative approach that involved 760 children aged 10-11 years old from 20 schools, including urban and rural schools located in the Northern Region of Malaysia, particularly in Kedah and Pulau Pinang. Middle childhood children were chosen as the respondents because children of this age explore the outdoor environment extensively, and they learn more from their environment (Mårtensson et al., 2014). The sample for the quantitative part was chosen based on stratified random sampling. Overall, the total sample size is 760 , with 383 children from Kedah and 378 children from Penang. Questionnaires were distributed to 760 children. The researcher read the questionnaire statements one by one and explained each statement so that the children had a better understanding of each statement. At the end of the session, a set of stationery was given to each child as a token of appreciation. 


\subsection{Questionnaire Development}

Children's experiences with nature were measured through three types of experiences which are 'direct experiences', 'indirect experiences', and 'non-nature experiences'. Direct experiences involve actual contact with nature through play and spontaneous activities in unstructured, unorganized, and unplanned areas, such as activities with plants, water activities, activities with earth elements, and activities with animals. Meanwhile, indirect experiences involve all activities other than direct experiences with nature, which include visits to organized and planned areas, as well as observation and vicarious learning activities. Non-nature experiences refer to the activities that the children always do as their hobbies that are not related to nature. Items for each type of experiences were constructed based on previous instruments, literature review findings and pre-test. The children were required to tick on the frequency of them doing the listed items.

Meanwhile, children's CTN was measured through six constructs: nature dependence, sense of responsibility, enjoyment in nature, empathy towards nature, interest in nature activities, and interest in natural spaces. Overall, there were 26 items, and the items for each construct were adapted from previous CTN instruments. The questionnaires were distributed in the Malay language. The children took 20 minutes to answer the questionnaire.

\subsection{Analyses}

The data were analysed using IBM SPSS Statistics Version 22. Descriptive analysis was used to analyse the percentage and frequency of children's background. Inferential analysis using independent samples t-test was used to identify the differences in age and gender for both experiences with nature and CTN among children.

\subsection{Findings}

\subsection{Children's Background}

As shown in Table 1, 50.3\% of the children were from Kedah and $49.7 \%$ were from Pulau Pinang. Out of $50.3 \%$ children from Kedah. Regarding age, $49.9 \%$ of the children were 10 years old and $50.1 \%$ were 11 years old. Regarding gender, $51.2 \%$ of the respondents were boys and $48.8 \%$ were girls. The sample size for each stratum was calculated based on proportionate calculation since the study employed stratified random sampling.

Table 1: Descriptive Analysis of Geographical Locations and Demographic Characteristics

\begin{tabular}{llcc} 
Table 1: Descriptive Analysis of Geographical Locations and Demographic Characteristics \\
\hline Category & Types & $\begin{array}{c}\text { Frequency } \\
\text { ( } \mathbf{n = 7 6 0 )}\end{array}$ & Percentage (\%) \\
\hline State & Kedah & 382 & 50.3 \\
& Pulau Pinang & 378 & 49.7 \\
\hline Age & 10 years old & 379 & 49.9 \\
& 11 years old & 381 & 50.1 \\
\hline Gender & Boy & 389 & 51.2 \\
& Girls & 371 & 48.8 \\
\hline Ethnic & Bumiputera & 737 & 97.0 \\
& Malay & 737 & 97.0 \\
& Non-bumiputera & 23 & 3.0 \\
& Chinese & 4 & 0.5 \\
& Indian & 14 & 1.8 \\
& Others & 5 & 0.7 \\
\hline
\end{tabular}

\subsection{Experiences in Nature across Age}

The results of the independent samples t-test for experiences in nature (direct experiences, indirect experiences, and non-nature experiences) across age (10 years old and 11 years old) are presented in Table 2.

Table 2: Independent-sample t-test Results for Experiences in Nature across Age

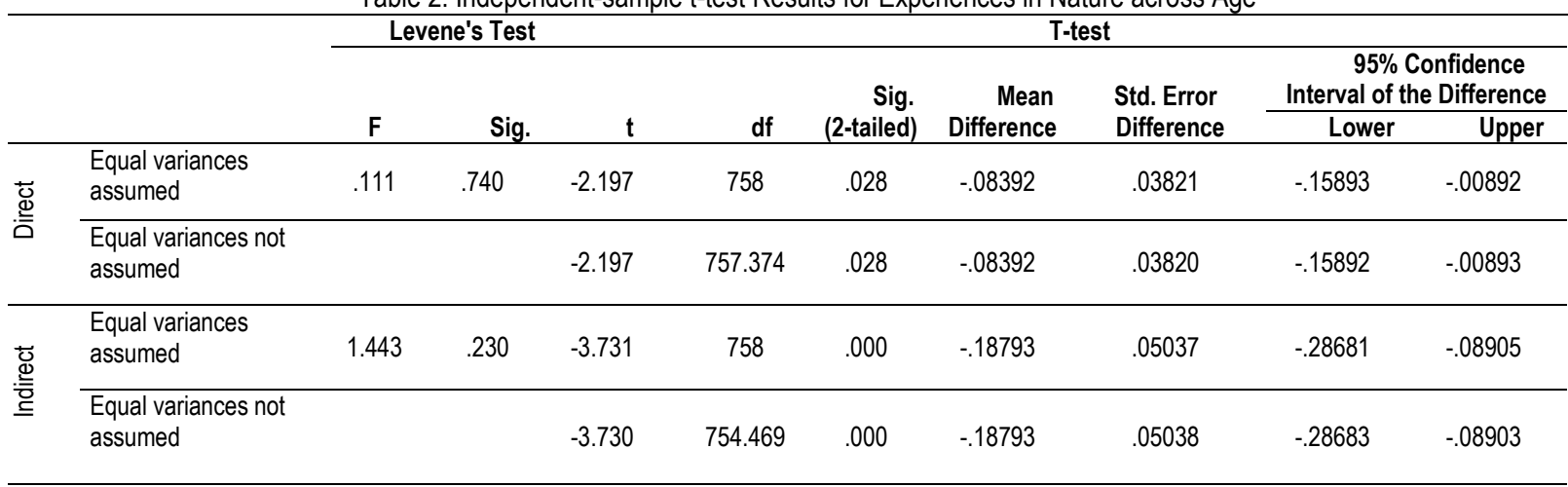




\begin{tabular}{|c|c|c|c|c|c|c|c|c|c|c|}
\hline \multirow{2}{*}{ 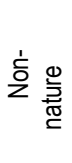 } & $\begin{array}{l}\text { Equal variances } \\
\text { assumed }\end{array}$ & 1.118 & .291 & -2.488 & 758 & .013 & -.13146 & .05284 & -.23518 & -.02773 \\
\hline & $\begin{array}{l}\text { Equal variances not } \\
\text { assumed }\end{array}$ & & & -2.488 & 754.551 & .013 & -.13146 & .05285 & -.23520 & -.02771 \\
\hline
\end{tabular}

As shown in Table 2, for direct experiences in nature, there is a significant difference in the scores of direct experiences in nature between age as follows: 10 years old $(M=2.22, S D=0.52)$ and 11 years old $(M=2.30, S D=0.54) ; t(760)=-2.20, p=0.03$, two-tailed). However, the effect size is small (eta squared $=0.01$ ). Regarding indirect experiences in nature, there is also a significant difference between the scores of indirect experiences in nature for age as follows: 10 years old $(M=2.62, S D=0.72)$ and 11 years old $(M=2.80$, $S D=0.67 ; t(760)=-3.73, p=0.00$, two-tailed). The magnitude of differences in the means is small (eta squared $=0.02$ ). Furthermore, there is a significant difference between the non-nature experiences scores for age as follows: 10 years old $(M=2.90, S D=0.75)$ and 11 years old $(M=3.03, S D=0.71, t(760)=-2.48, p=0.01)$. The effect size is small (eta squared= 0.01 ). The results suggest that 11 -yearold children have significantly more experiences in nature, both direct and indirect, as well as non-nature experiences.

\subsection{Experiences in Nature across Gender}

The results of the independent samples t-test for experiences in nature (direct experiences, indirect experiences, as well as non-nature experiences) across gender (boys and girls) are presented in Table 3.

Table 3: Independent-sample t-test Results for Experiences in Nature across Gender

\begin{tabular}{|c|c|c|c|c|c|c|c|c|c|c|}
\hline & & \multicolumn{4}{|c|}{ Levene's Test } & \multicolumn{5}{|c|}{ T-test } \\
\hline & & \multirow[b]{2}{*}{$F$} & \multirow[b]{2}{*}{ Sig. } & \multirow[b]{2}{*}{$t$} & \multirow[b]{2}{*}{ df } & \multirow{2}{*}{$\begin{array}{l}\text { Sig. (2- } \\
\text { tailed) }\end{array}$} & \multirow{2}{*}{$\begin{array}{c}\text { Mean } \\
\text { Difference }\end{array}$} & \multirow{2}{*}{$\begin{array}{l}\text { Std. Error } \\
\text { Difference }\end{array}$} & \multicolumn{2}{|c|}{$\begin{array}{c}95 \% \text { Confidence Interval } \\
\text { of the Difference }\end{array}$} \\
\hline & & & & & & & & & Lower & Upper \\
\hline \multirow{2}{*}{ 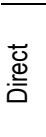 } & $\begin{array}{l}\text { Equal variances } \\
\text { assumed }\end{array}$ & 4.892 & .027 & 1.640 & 758 & .101 & .06276 & .03827 & -.01237 & .13789 \\
\hline & $\begin{array}{l}\text { Equal variances not } \\
\text { assumed }\end{array}$ & & & 1.645 & 752.402 & .100 & .06276 & .03815 & -.01213 & .13765 \\
\hline \multirow{2}{*}{ 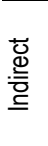 } & $\begin{array}{l}\text { Equal variances } \\
\text { assumed }\end{array}$ & 4.892 & .027 & 1.640 & 758 & .101 & .06276 & .03827 & -.01237 & 13789 \\
\hline & $\begin{array}{l}\text { Equal variances not } \\
\text { assumed }\end{array}$ & & & .409 & 756.394 & .683 & .02077 & .05084 & -.07903 & 12057 \\
\hline \multirow{2}{*}{\multicolumn{2}{|c|}{ 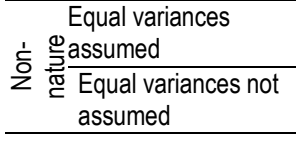 }} & .097 & .755 & 7.253 & 758 & .000 & .37221 & .05132 & .27147 & .47295 \\
\hline & & & & 7.251 & 755.306 & .000 & .37221 & .05133 & .27144 & .47298 \\
\hline
\end{tabular}

Table 3 indicates that there is no statistically significant difference in the direct experiences scores between gender, boy ( $M=2.29$, $S D=0.56)$ and girls $(M=2.23, S D=0.49) ; t(760)=1.65, p=0.10$, two-tailed). In addition, there is no significant difference between indirect experiences for gender as follows: boys $(M=2.72, S D=0.70)$ and girls $(M=2.70, S D=0.70 ; t(760)=0.41, p=0.68$, two-tailed). However, there is a significant difference of non-nature experiences between gender as follows: boys $(M=3.15, S D=0.70)$ and girls $(M=2.78, S D=$ $0.71, t(760)=7.25, p=0.00$ ). The effect size is moderate with eta squared of 0.06 . The results suggest that boys have a significantly higher score compared to girls for non-nature experiences.

\subsection{Connectedness to Nature across Age and Gender}

The results of the independent samples t-test for CTN scores across age (10 years old and 11 years old) and gender (boys and girls) are shown in Table 4.

Table 4: Independent-samples t-test Results for CTN across Age and Gender

\begin{tabular}{|c|c|c|c|c|c|c|c|c|c|c|}
\hline & & \multicolumn{3}{|c|}{ Levene's Test } & \multicolumn{4}{|c|}{ T-test } & \multirow{2}{*}{\multicolumn{2}{|c|}{$\begin{array}{l}95 \% \text { Confidence Interval } \\
\text { of the Difference }\end{array}$}} \\
\hline & & \multirow[b]{2}{*}{$\mathrm{F}$} & \multirow[b]{2}{*}{ Sig. } & \multirow[b]{2}{*}{$t$} & \multirow[b]{2}{*}{ df } & \multirow{2}{*}{$\begin{array}{r}\text { Sig. } \\
\text { (2-tailed) }\end{array}$} & \multirow{2}{*}{$\begin{array}{r}\text { Mean } \\
\text { Difference }\end{array}$} & \multirow{2}{*}{$\begin{array}{l}\text { Std. Error } \\
\text { Difference }\end{array}$} & & \\
\hline & & & & & & & & & Lower & Upper \\
\hline \multirow{2}{*}{ 通 } & $\begin{array}{l}\text { Equal variances } \\
\text { assumed }\end{array}$ & 9.816 & .002 & -4.783 & 758 & .000 & -.11657 & .02437 & -.16442 & -.06873 \\
\hline & $\begin{array}{l}\text { Equal variances not } \\
\text { assumed }\end{array}$ & & & -4.781 & 738.881 & .000 & -.11657 & 02438 & -.16444 & -.06871 \\
\hline ৩ & $\begin{array}{l}\text { Equal variances } \\
\text { assumed }\end{array}$ & 3.112 & .078 & -2.848 & 758 & .005 & -.07008 & .02461 & -.11840 & -.02177 \\
\hline
\end{tabular}


Equal variances not

assumed

$-2.854$

756.696

.004

$-.07008$

.02456

$-.11830$

$-.02187$

As shown in Table 4, there is a statistically significant difference in the CTN scores between age, 10 years old $(M=3.25, S D=0.36)$ and 11 years old $(M=3.37, S D=0.31, t(760)=-4.78, p=0.00)$. However, the effect size is small (eta squared $=0.03)$. In addition, there is a significant difference in the CTN scores between gender, boys $(M=3.28, S D=0.35)$ and girls $(M=3.35, S D=0.32, t(760)=-2.85$, $p=0.01$ ). The effect size is also small with eta squared 0.01 . This suggests that 11-year-old children have higher CTN than have 10year-old children. In addition, girls have higher CTN than have boys.

\subsection{Discussion Findings}

As for experiences with nature, regarding age, there is a significant difference in the mean scores for direct experiences in nature between different age groups. The group of 11-year-old children have higher mean scores of direct experiences compared to the 10year-old group. For indirect experiences in nature, the findings also revealed that there is a significant difference between age groups with the 11-year-olds having a higher mean score for indirect experiences in nature compared to the 10-year-old children. In addition, there is a significant difference in the mean scores for non-nature experiences in nature between children of different ages. The findings indicate that 11-year-old children are more active in the outdoor environment. They are more explorative and independently mobile away from home; thus, they have significantly more direct, indirect, and non-nature experiences in nature.

Regarding gender, several studies have demonstrated that girls are more attached to nature than are boys (Zelezny et al., 2000) because girls are more active in the home yard, whereas boys tend to be active in sporting activities (Min \& Lee, 2006). However, the findings of this study contradict the findings of those studies. The findings in this study show that there is no significant difference in the mean scores for direct experiences between the genders, with boys having a slightly higher mean score of direct experiences in nature compared to girls. Therefore, boys have slightly more direct experiences compared to girls, and this may be related to parents' caution, which is greater towards girls than towards boys, which may limit the opportunities girls have to play in the outdoor environment where they can obtain experiences with nature. However, the difference is insignificant, as there is a reduction in direct experiences for both boys and girls. Similarly, for indirect experiences in nature, there is no significant difference in the mean scores between boys and girls, with boys having a slightly higher mean score. However, regarding non-nature experiences in nature, there is a significant difference in the mean scores between boys and girls with boys having a higher mean score for non-nature experiences compared to girls. This is in accordance with previous studies, which found that boys play more in the outdoor environment (Min \& Lee, 2006) and have more independent mobility (Prezza et al., 2001). These findings suggest that boys play more in the outdoor environment, as boys have significantly more non-nature experiences compared to girls and have slightly more direct and indirect experiences in nature.

As for CTN, regarding age, children aged 11 years old have significantly higher CTN than children aged 10-years old. This can be explained by the fact that as the children get older, they have more knowledge of nature through experiences with nature, which in turn, affects their CTN. Meanwhile, for gender, girls have significantly higher CTN levels than have boys. Even though boys were shown to have more experiences with nature (direct and indirect experiences with nature), surprisingly, girls have higher levels of CTN. This finding suggests that there might be other factors other than experiences with nature that contribute to higher level of children's CTN among girls. The findings for gender are consistent with previous studies, which found that girls have higher CTN (Alp et al., 2006; Zelezny et al., 2000).

Findings have shown children with the same age and gender from different cultures have slightly similarities in engagement with nature. This study found older children are more explorative and independently mobile from home and are more connected to nature. Meanwhile, as for gender, boys are more explorative and have more experiences with nature as compared to girls. However, girls who are more connected to nature. Findings suggest there are other factors that contribute to children's CTN other than frequent experiences with nature. For examples, knowledge is one the factor that contribute to children's CTN as children get older, they have obtained more knowledge and thus are more connected to nature.

\subsection{Conclusion \& Recommendations Findings}

In conclusion, boys have more experiences with nature (direct experiences, indirect experiences, and non-nature) than have girls. However, girls have higher CTN. Concerning age, 11-year-old children have more experiences with nature and have higher CTN than have 10-year-old children. Other factors that contribute to higher level of CTN among girls since girls have higher level of CTN compared to boys need to be explored in future research. Future research also needs to be conducted with children aged 7-9 years old (younger children) and involve other schools not only in Sekolah Kebangsaan (SK) to identify the differences in how children with different ethnicities experience nature and are connected to nature. Also, future research needs to consider the use of a qualitative approach to investigate in-depth the differences of age and gender in children's experiences in nature and their CTN.

\section{Acknowledgements}

The authors would like to acknowledge the Short-Term Grant (SJGP) R/SGJP/A1200/01723A/001/2019/00647 and University Malaysia Kelantan for continuous support. 


\section{Paper Contribution to Related Field of Study}

This paper contributes to the body of knowledge on the age and gender differences of children's experiences with nature and CTN, especially in the Malaysian context.

\section{References}

Alp, E., Ertepinar, H., Tekkaya, C., \& Yilmaz, A. (2006). A statistical analysis of children's environmental knowledge and attitudes in Turkey. International Research in Geographical and Environmental Education, 15(3), 210-223.

Capaldi, C. A., Dopko, R. L., \& Zelenski, J. M. (2014). The relationship between nature connectedness and happiness: A meta-analysis. Frontiers in Psychology, 5(2014), $1-17$.

Castonguay, G., \& Jutras, S. (2009). Children's appreciation of outdoor places in a poor neighborhood. Journal of Environmental Psychology, 29(1), 101-109.

Collado, S., \& Corraliza, J. A. (2012). Perceived restoration and environmental orientation in a sample of Spanish children. Procedia - Social and Behavioral Sciences, $38,264-274$

Deng, J. (2006). A comparison of environmental values and attitudes between Chinese in Canada and Anglo-Canadians. Environment and Behavior, 38(1), $22-47$.

Fjørtoft, I., \& Sageie, J. (2000). The natural environment as a playground for children: Landscape description and analyses of a natural playscape. Landscape and Urban Planning, 48, 83-97.

Gundersen, V., Skår, M., O'Brien, L., Wold, L. C., \& Follo, G. (2016). Children and nearby nature: A nationwide parental survey from Norway. Urban Forestry and Urban Greening, 17, 116-125.

Holt, N. L., Lee, H., Millar, C. A., \& Spence, J. C. (2015). 'Eyes on where children play': A retrospective study of active free play. Childrens Geographies, 13(1), 73-88.

Howell, A. J., Dopko, R. L., Passmore, H.-A., \& Buro, K. (2011). Nature connectedness: Associations with well-being and mindfulness. Personality and Individual Differences, 51(2), 166-171.

Kahriman-Ozturk, D., Olgan, R., \& Tuncer, G. (2012). A qualitative study on Turkish preschool children's environmental attitudes through ecocentrism and anthropocentrism. International Journal of Science Education, 34(4), 629-650.

Korpela, K., Kyttä, M., \& Hartig, T. (2002). Restorative experience, self-regulation, and children's place preferences. Journal of Environmental Psychology, 22(4), 387398.

Louv, R. (2008). Last children in the woods. Saving our children from nature-deficit disorder. Chapel Hill, NC: Algonquin Books.

Mahidin, A. M. M., \& Maulan, S. (2012). Understanding children preferences of natural environment as a start for environmental sustainability. Procedia - Social and Behavioral Sciences, 38, 324-333.

Mårtensson, F., Jansson, M., Johansson, M., Raustorp, A., Kylin, M., \& Boldemann, C. (2014). The role of greenery for physical activity play at school grounds. Urban Forestry \& Urban Greening, 13(1), 103-113.

Mayer, F. S., \& Frantz, C. M. (2004). The connectedness to nature scale: A measure of individuals' feeling in community with nature. Journal of Environmental Psychology, 24(4), 503-515.

Milfont, T. L. (2012). Cultural differences in environmental engagement. In S. Clayton (Ed.), The Oxford Handbook of environmental and conservation (pp. 181-200). New York: Oxford University Press.

Min, B., \& Lee, J. (2006). Children's neighborhood place as a psychological and behavioral domain. Journal of Environmental Psychology, $26(1), 51-71$.

Mustapa, N. D., Maliki, N. Z., Aziz, N. F., \& Hamzah, A. (2018). The differences of nature experiences between urban and rural children. Geografia: Malaysian Journal of Society and SpaceMalaysian Journal of Society and Space, 4(4), 225-237.

Mustapa, N. D., Maliki, N. Z., \& Hamzah, A. (2018). Benefits of Nature on Children 's Developmental Needs : A Review. Asian Journal of Behavioural Studies, 3(12), 31.

Phenice, L. A., \& Griffore, R. J. (2003). Young children and the natural world. Contemporary Issues in Early Childhood, 4(2), 167-171.

Prezza, M., Pilloni, S., Morabito, C., Sersante, C., Alparone, F. R., \& Giuliani, M. V. (2001). The influence of psychosocial and environmental factors on children's independent mobility and relationship to peer frequentation. Journal of Community \& Applied Social Psychology, 11, 435-450.

Ridgers, N. D., Knowles, Z. R., \& Sayers, J. (2012). Encouraging play in the natural environment: A child-focused case study of forest school. Children's Geographies, 10(1), 49-65.

Salı, G., Akyol, A. K., \& Baran, G. (2014). An analysis of pre-school children's perception of schoolyard through their drawings. Procedia - Social and Behavioral Sciences, $116,2105-2114$

Sorin, R., \& Gordon, I. J. (2012). Developing a methodology to assess children's perceptions of the tropical environment. International Education Studies, 6(2), 96-109.

Tam, K.-P., Lee, S.-L., \& Chao, M. M. (2013). Saving Mr. Nature: Anthropomorphism enhances connectedness to and protectiveness toward nature. Journal of Experimental Social Psychology, 49(3), 514-521. 
Torquati, J., \& Ernst, J. A. (2013). Beyond the walls: Conceptualizing natural environments as "third educators." Journal of Early Childhood Teacher Education, 34(2), $191-208$.

Wilson, E. O. (1984). Biophilia. Cambridge, MA: Harvard University Press.

Zelezny, L. C., Chua, P.-P., \& Aldrich, C. (2000). Elaborating on gender differences in environmentalism. Journal of Social Issues, 56(3), 443-457.

Zhang, W., Goodale, E., \& Chen, J. (2014). How contact with nature affects children's biophilia, biophobia and conservation attitude in China. Biological Conservation, $177,109-116$ 